\title{
AGRICULTURAL RESOURCES AND DEVELOPMENT PRIORITIES OF THE MUNICIPALITY OF STARA PAZOVA ${ }^{1}$
}

\author{
Branko Mihailović2 ${ }^{2}$ Zoran Simonovićc ${ }^{3}$, Nikola Ć určić ${ }^{4}$
}

\begin{abstract}
This paper examines the agricultural potentials of Stara Pazova, and consequently defines development priorities in this area. The aim at the research is to assess the real possibilities for improvement on agriculture Municipality. The analysis is focused on: knowledge transfer and innovation, agriculture technical equipment, warehouse and finishing capacities in agriculture, processing of agricultural products and the vision and development priorities over agriculture Municipality. The research results show that the improvement to the competitiveness of the agricultural sector of Stara Pazova requires the implementation of adequate policy measures and projects related to the improvement to human resources, higher level of processing of agricultural and food products, as well as better agricultural technical equipment agricultural producers. Activities in this area include primarily higher correlation science and practice across the reorganized agricultural station, extension services, home service, agricultural cooperatives and other associations of farmers; development and implementation of new knowledge and skills of farmers through advice, training, seminars, courses; support young farmers in the modernization of farms. All projects in this field must be based on adequate state support and coordinated efforts of the public and private sectors.
\end{abstract}

Keywords: agriculture, knowledge transfer, storage and finishing capacity, development priorities.

JEL: Q01, Q12, Q15.

1 Paper is a part of research within the project no. III 46006 - Sustainable agriculture and rural development in the function of accomplishing strategic objectives of the Republic of Serbia in the Danube region, financed by the Ministry of Education, Science and Technological Development of the Republic of Serbia. Project period: 2011-2017.

2 Branko Mihailović Ph.D., Senior Research Associate, Institute of Agricultural Economics, Volgina Street no. 15, 11060 Belgrade, Serbia, Phone: +381 1169728 58, E-mail: brankomih@neobee.net.

3 Zoran Simonović Ph.D., Scientific Associate, Institute of Agricultural Economics, Volgina Street no. 15, 11060 Belgrade, Serbia, Phone: +381 1169728 58, E-mail: zoki@medianis.net.

4 Nikola Ćurčić M.A., Teaching assistant, University Union, „Nikola Tesla“, Belgrade, Faculty of Management, Njegoševa 1a, 21205, Sremski Karlovci, Serbia, Phone: +381 2121550 45, nikolavcurcic@yahoo.com.

EP 2017 (64) 1 (259-274) 


\section{Introduction}

Inadequate economic development of Serbia is determined by many factors, among which the following stand out: unfavorable structure of the economy, the loss of traditional markets, financial indiscipline and lack of investment in existing and new enterprises. According to experts on the World Bank need to be $40 \%$ of the national income created in new sectors in order to annul the negative effects of the transition shock. However, even after the year 2000 in Serbia established a growing trend of investment, they are insufficient for the transformation of the 'factors led' 'to' 'investments trailed' economy characterized by sustainable development (Porter, 1990). Consequently, the current growth is not sustainable without a significant increase in investment.

Insufficient investment in new production programs and represents a limiting factor on export growth, due to the absence of qualitative factors of competitiveness. Production of agricurtual market potential and its place in the national economy opens significant opportunities for industry revitalization of agricultural inputs (Milanović, Stevanovic, Dimitrijević, 2016). Accordingly, the crucial issue of Serbia in the coming period is the sustainable economic growth, competitiveness and growth of enterprises and the growth of exports. Completion of market institutions, in particular the development of financial markets, infrastructure, efficient state administration and judiciary, reducing corruption - is necessary preconditions for the development of a stimulating business environment in Serbia. The great potential for agricultural -industrial complex about Serbia, could be a very good basis of the efficient development of agricultural -industry and increasing competitiveness in the markets of EU, Russia and many other countries, bearing in mind that the total demand for organic healthy food to grow rapidly in the coming period ( Savić, Bošković, Micic, 2016). Unfortunately, the Serbian-dominated agrarian exports primary agricultural products and products with a low degree of added value. According to the structure of exports of agriculture was dominated by fruits and vegetables with $26.66 \%$, followed by cereals from $22.27 \%$ to $8.78 \%$ tobacco and drinks with $6.60 \%$ (Serbian Chamber of Commerce, 2016). Consequently, municipalities in Serbia in their development strategies should be based on innovation, regional recognition and investment in products of higher level of added value.

The territory of the municipality of Stara Pazova covers an area in the southern part of the Pannonia Plain, and occupies the eastern Srem. The municipality is located in the plain area, a plot of the territory of the extraordinary fertility. Altitude is approximately 80 meters. Stara Pazova no rivers in their area, there are only artificially dug channels. The nearest river is the Danube, which is $10 \mathrm{~km}$ away from Stara Pazova, runs through the Stari Banovce. Otherwise river Danube flows through eastern border of the municipality in the length of $24 \mathrm{~km}$. The Municipality of Stara Pazova is situated in the southeastern part of Srem, in the Autonomous Province of Vojvodina, which occupies the northern part of Serbia. A belongs Srem authorities (City Sremska Mitrovica and the Municipality of Sid, Indjija, Irig, Ruma, Stara Pazova and Pećinci). In the municipality of Stara Pazova live 65,792 inhabitants, of which live in the town of 18,602 $(59.30 \%)$ and in the suburbs 47.190 inhabitants $(40,70 \%)$. The population density of 
the municipality of Stara Pazova in 2011 was 200 people per square kilometer (Rural Development Strategy of the Municipality of Stara Pazova for the period 2015 to 2025 years). The demographic picture points of the necessity of taking appropriate measures and strategies to adapt to the development of rural areas of the current demographic situation (Nikolić, 2006).

The Regional Plan R. Serbia, the municipality of Stara Pazova in the wider regional context should be connected with the City of Belgrade and other municipalities in the region (Pećinci, Ruma, Stara Pazova, Pancevo, Smederevo, Smederevska Palanka, Ub and Lajkovac), and form into the metropolitan basis, with City of Novi Sad over Inđije (Law on the spatial plan of the Republic of Serbia from 2010 to 2020). In this way, this area through the instrumentalists of their position and capacity to become one of the leading metropolitan $\mathrm{s}$ in this part of Europe, thanks to their institutional and human resource capacity, as well as the economic and cultural potential (Law on the Spatial Plan of the Republic of Serbia from 2010 to 2020).

\section{Methodology and data sources}

In order to implement the research task will use all available sources of information:

- Official national statistics, i.e. the data onto the Republic Institute for Statistics;

- National and municipal strategies and development documents in the specific field;

- Materials Serbian Chamber of Commerce and other local institutions and organizations;

- Studies of domestic and foreign authors in the subject area;

- Research by the Institute of Agricultural Economics and his associates realized in the previous period.

The realization of the research task, which relates to the assessment of agricultural potential and defining development priorities to the municipality of Stara Pazova, will be used to analyze secondary data (primarily from the 2012 Census of Agriculture), the spatial analysis of relevant variables as well as research based on focus groups composed of actors interested in agricultural municipality of Stara Pazova. By combining the aforementioned methods of research can be obtained as reliable answers to key questions that arise from the context of the analysis of agricultural resources and development priorities of the municipality of Stara Pazova.

\section{Results with Discussion}

The Municipality of Stara Pazova has one of the longest traditions when it comes to the development of small and medium-sized enterprises in Serbia. In the municipality are now about five hundred small and medium-sized enterprises. Also in the municipality is located in and around two thousand and six hundred craft shops most of which are located in Stara Pazova and Nova Pazova (Rural Development Strategy of the Municipality of Stara Pazova for the period 2015 to 2025 years). Since the industry 
is represented by wood-industrial Company, the factory metals products factory machinery, brick plant and others. In recent years, municipalities have been very active in terms of industrialization and the development of new industrial zones, attracting new investors. When it comes to the distribution of industries in residential areas, almost 30\% is located in Stara Pazova, 25\% in Nova Pazova, $8 \%$ and 6\% in Banovci. Stari Banovci, while $22 \%$ located outside the territory of the village. Belegiš, Vojka, and Krnješevci Surduk are hosts for 9\% of enterprises (Rural Development Strategy of the Municipality of Stara Pazova for the period 2015 to 2025 years).

Agriculture contributes to the development of the local economy. According to the same source, in the municipality is about 29.982 hectares of arable land, of which approximately 22.000 hectares are privately owned. Farming is the main occupation in rural areas of the municipality. Analysis of the economic structure of the municipality shows that one third of the total earnings from the manufacturing industry, while agriculture, trade and the service sector contributing each with $25 \%$. Other branches provide less than $10 \%$ of total earnings. When it comes to investments, the Municipality of Stara Pazova invested the most in the manufacturing industry, commerce and agriculture, while investment in the construction of infrastructure projects for water management in 2012 amounted to only 1\%. In terms of the structure of the industry represented in the municipality of Stara Pazova, agriculture deals with $22.9 \%$ of the total population. Other most represented industries are: industry $27.3 \%$ and services 49.8\%. Income that municipalities Stara Pazova realized from agriculture is $22.4 \%$. (The strategy of sustainable development of the municipality to Stara Pazova from 2010 to 2020).

Transfer of knowledge and innovation. Company with developed agriculture and efficient institutions, timely noted the importance of knowledge as an important factor of modernization of agricultural production and so far are relatively successfully enabled its transfer of the end users (Petrović, Čikić, 2005). However, current systems of knowledge transfer and innovation in Serbia are insufficiently effective and do not follow sufficiently accelerated technical and technological changes. However, the existing scientific and educational institutions in the field of agriculture have relatively quality staff, who scored a number of internationally recognized and acknowledged results of new varieties, breeds and strains, scientific papers and technical solutions (Republic of Serbia IPARD program 2014-2020). In the agribusiness sector education and extension are important factors modernization business. In support of this statement must be given a confirmed fact that investment in the extension (and agricultural research) yields to $40 \%$ of the average wage rate, which is "much more than other investments in agricultural development" (Van den Ban, Hawkins, 1996). The affirmation of the knowledge economy requires a greater investment in basic research. However, longterm crisis of the domestic economy has led to a reduction of accumulative capacity of enterprises in Srem authorities and Stara Pazova. In such circumstances, there is no critical mass of resources needed for organizing the research process, as well as the willingness to take financial risks that these processes nose. In Serbia, the transfer of 
knowledge and innovation in the field of agriculture implemented through the formal education system, through various types of training organized by educational and research institutions and organizations, IPRS, a private business companies, project units, the media, etc. (The Strategy of Agriculture and Rural Development Serbia for the period 2014-2020). At the same time, it should be noted that the current structures and system of knowledge transfer are not effective enough and fail to adequately meet the needs of dynamic technical and technological restructuring of the agricultural sector (Agriculture and Rural Development of the Republic of Serbia for the period 2014-2020).

The strategic objective in the field of economy of Stara Pazova, the development of the social market economy conditions and instrument of sustainable development of local communities, and smart, sustainable and inclusive growth of the local community (Revision of the sustainable development strategy of Stara Pazova, 2015). The first priority to the achievement of this strategic objective: Development of a smart economy based on knowledge, innovation, entrepreneurship and the information society (Revision of the sustainable development strategy of Stara Pazova, 2015). In the area of agriculture and rural development knowledge transfer and innovation is realized through:

- Agricultural Extension Service "Sremska Mitrovica” Ltd. Sremska Mitrovica;

- Department of Agriculture, Forestry and Water Management of Municipal Administration Stara Pazova, which performs administrative and professional tasks in the field of Agriculture, Water and Forestry. The department makes the connection between producers, agricultural cooperatives and associations, regional agricultural departments and the ministry;

- Economic - Trade School "Vuk Karadzic" and "Technical School” in Stara Pazova.

Agricultural Extension Service "Sremska Mitrovica" Ltd. Sremska Mitrovica covers four municipalities: Sremska Mitrovica, Sid, Pećinci, and Stara Pazova with 69 settlements on 153,000 ha of arable land (www.polj.savetodavstvo.vojvodina.gov.rs). Sowing structure of municipalities is similar to the most commonly grown cereals, corn, oil crops, forage crops, sugar beet, tobacco and vegetables. Fruit and vine becomes more and more interesting to the slopes of the part of the territory covered by our professional service. The specificity of the production of vegetables in the open and indoors was particularly evident in the Mačva part in the municipalities Sremska Mitrovica and Pecinci because of the tradition, the specific soil conditions and proximity to major cities. According to the Agricultural Census data onto 2012, the number of farms that used the services of advisory services in Stara Pazova was 638 (Census of Agriculture 2012 Other information about the farm, the level of settlements). This is only $17.4 \%$ of the total number of farms in Stara Pazova $(3,664)$, which is at the average level of the Republic of Serbia (only 17\% of farms used the services of advisory services). Observed by towns, farms that are most used services advisory services were recorded in the following settlements: Vojka and Golubinci (at 148), Stara Pazova (80), Surduk 
(76) and Belegiš (66). Probably would transfer knowledge and innovation would be better if the farmers used computers and the Internet. In 2012 Census of Agriculture data shows that in the period 2011-2012 only 116 farms benefit of computers, which is only $3.2 \%$ of the total number of farms in Stara Pazova (Census of Agriculture 2012 other information about the farm, the level of settlements). For program activity, "incentives for agricultural production", in 2016 the budget of the municipality of Stara Pazova planned amount of 5.5 million dinars, of which (Official Gazette of the Srem Municipalities "No 35/15):

- 5,000,000 dinars is allocated for subsidies in agriculture and education authorities. In addition to educational character and adoption of new technologies in production, this incentive promotes the spirit of competition in the production, showing the achievements of manufacturers and the results achieved in agriculture. The beneficiaries of this measure are rural local communities, citizens' associations, entrepreneurs and legal entities for the provision of advisory and other services, scientific and technical institutions.

- 500,000 dinars is allocated for the exhibition event in the field of agriculture. These funds are intended for the organization of fairs, exhibitions, events, etc.

In terms of further enhancing knowledge transfer and innovation in agriculture and rural development in Stara Pazova, it is important to bear in mind the following:

- Define larger amounts in the budget of the city of Stara Pazova fair event in the field of agriculture;

- Improving knowledge transfer and innovation in agriculture Stara Pazova constitution requires market-oriented companies with highly educated staff and the application of modern technologies of agricultural production;

- It is necessary to stimulate the partnership between the public and private sectors, as well as inter-sectional mobility of researchers, professors and consultants;

- Transfer of knowledge and information activities should be supported through various workshops, conferences, demonstration activities, information activities and short-term exchange programs and visits to farms (EU Regulation 1305/2013).

Agricultural-technical equipment's. In consideration of economic and social factors are important to the development of family farms is of particular importance is the analysis of their production capacities (Maletić, Popović, 2016). Unfortunately, in Serbia in the last decades has been a differentiation and stratification of the rural population, which is the main carrier of agricultural production (Agricultural Census 2012 Agricultural machinery, equipment and facilities in the Republic of Serbia). The study showed that experienced producers who have greater economic power, which allows them to monitor new technological developments, both in terms of the use of new equipment, as well as the application of new technologies. In the second group are those poorer without sufficient funds of a serious change, and there is a large majority of Serbia. According to data onto the 2012 Census of Agriculture (Volume 1) in Stara Pazova registered: 314 single-axle tractor; 2,331 two-axle tractors and 132 
harvesters. When connecting machines registered the following condition are: 381 picker, 1,965 plows, 380 disc harrows, 1,128 harrows, 922 preparing combination, 56 rot tiller, 975 Mineral spreaders, 146 manure spreaders, 658 seeder, 1,005 sprayer, 2,296 trailers and 316 machines. Every farm in Stara Pazova on average has 3.55 units of auxiliary machines and equipment (3.9 average for the Republic of Serbia), which is slightly less favorable than the average in the Republic of Serbia. Spatial distribution of agricultural machinery by settlements (Table 1) showed that the settlement with the largest agricultural engineering equipment at the following: Golubinci, Vojka and Belegiš. At the same time, the lowest agricultural technical equipment is: Novi Sad, Nova Pazova and Krnješevci. For the village, Surduk and Stari Banovci can be said to have average agricultural technical equipment, with a certain oscillation number of agricultural machinery by settlements.

Table 1. Agriculture - the number for the level of regions and the city of Stara Pazova, data by settlements

\begin{tabular}{|l|r|r|r|r|r|}
\hline Area, town, village & Axle tractors & $\begin{array}{c}\text { Two-axle } \\
\text { tractors }\end{array}$ & $\begin{array}{c}\text { Universal grain } \\
\text { harvesters }\end{array}$ & $\begin{array}{l}\text { Propelled Forage } \\
\text { harvesters }\end{array}$ & Other harvesters \\
\hline Srem area & $\mathbf{1 . 6 1 5}$ & $\mathbf{1 9 . 4 0 4}$ & $\mathbf{1 . 0 6 3}$ & $\mathbf{9 4 4}$ & $\mathbf{5 3}$ \\
\hline Stara Pazova & $\mathbf{3 1 4}$ & $\mathbf{2 . 3 3 1}$ & 10 & $\mathbf{3 3}$ & $\mathbf{6}$ \\
\hline Belegiš & 32 & 283 & 25 & 10 & $\mathrm{P}$ \\
\hline Vojka & 30 & 429 & 12 & 5 & $\mathrm{P}$ \\
\hline Golubinci & 46 & 495 & 4 & 4 & $\mathrm{P}$ \\
\hline Krnješevci & 4 & 120 & $\mathrm{P}$ & $\mathrm{P}$ & $\mathrm{P}$ \\
\hline Nova Pazova & 29 & 58 & $\mathrm{P}$ & $\mathrm{P}$ & $\mathrm{P}$ \\
\hline Novi Banovci & 18 & 56 & 19 & $\mathrm{P}$ & $\mathrm{P}$ \\
\hline Stara Pazova & 109 & 470 & 9 & $\mathrm{P}$ & $\mathrm{P}$ \\
\hline Stari Banovci & 27 & 236 & 12 & $\mathrm{P}$ & $\mathrm{P}$ \\
\hline Surduk & 19 & 184 & & $\mathrm{P}$ \\
\hline
\end{tabular}

Source: Census of Agriculture 2012, Agricultural machinery, the level of the village, Republic Statistical Office, Republic of Serbia,

http://popispoljoprivrede.stat.rs/?page_id=6221. Join Date 10.12.2015.

Note: In accordance with the Law on Official Statistics and the protection of personal data, some data onto the tables for settlements of three or less than three holdings are hidden or displayed with the letter "P".

As for the age of agricultural machinery, it is important to emphasize that on Stara Pazova $95.8 \%$ corn picker older than 10 years and is technically obsolete and should be purchased new. The data presented in Table 2 indicate that in some villages such as Stari Banovci and Novi Sad, all the maize pickers are older than 10 years. 
Table 2. Picking corn - the number by settlements

\begin{tabular}{|l|r|r|r|r|}
\hline \multirow{2}{*}{ Area, town, village } & \multicolumn{4}{|c|}{ Pickers corn } \\
\cline { 2 - 6 } & In total & $\begin{array}{c}\text { of which: older than } 10 \\
\text { years }\end{array}$ & Own number & not owned \\
\hline Area, town, village & $\mathbf{2 . 6 9 8}$ & $\mathbf{2 . 5 9 7}$ & $\mathbf{2 . 4 4 8}$ & $\mathbf{8 . 6 7 1}$ \\
\hline Stara Pazova & $\mathbf{3 8 1}$ & $\mathbf{3 6 5}$ & $\mathbf{3 3 0}$ & $\mathbf{9 1 8}$ \\
\hline Belegiš & 41 & 36 & 38 & 59 \\
\hline Vojka & 56 & 55 & 52 & 227 \\
\hline Golubinci & 45 & 44 & 36 & 128 \\
\hline Krnješevci & 19 & 15 & 19 & 41 \\
\hline Nova Pazova & 8 & 7 & 6 & 119 \\
\hline Novi Banovci & 5 & 5 & 5 & 62 \\
\hline Stara Pazova & 124 & 121 & 103 & 183 \\
\hline Stari Banovci & 47 & 47 & 38 & 65 \\
\hline Surduk & 36 & 35 & 33 & 34 \\
\hline
\end{tabular}

Source: Census of Agriculture 2012, Agricultural machinery, the level of the village, Republic Statistical Office, Republic of Serbia.

Note: In accordance with the Law on Official Statistics and the protection of personal data, some data in the tables for settlements with three or less than three holdings are hidden or displayed with the letter "P".

Relevant companies to produce and sell agricultural machinery in Stara Pazova are (http://mtt.gov.rs/informacije/baza-trgovackih-preduzeca-i-preduzetnika): POLJO ELIT- Vojka, entrepreneur, machinery for agriculture; BELI BREG- Vojka, machinery for agriculture and trade; BOROINEKS Company for trade and services doo, Stara Pazova; Wholesale of agricultural machinery, equipment and supplies; Company for Production, Trade and Services AGRO-LINE DOO, Golubinci; Wholesale of agricultural machinery, equipment and supplies; Company for production, trade and services AGROART DOO, Stara Pazova; Wholesale of agricultural machinery, equipment and supplies; Economic Society for production and domestic and foreign trade DEMETRA-LANCI DOO, Stara Pazova. Wholesale trade of agricultural machinery, equipment and supplies.

Problems that farmers in Stara Pazova are in the field of agricultural machinery are as follows: 1) Certain types of existing machine park (maize pickers) are technologically obsolete; 2) Unfavorable bank loans for the purchase of new machinery and 3) Insufficient cooperation of farmers in the area use the common machinery (undeveloped machinery rings), which would cost mechanization could significantly decrease and increase economic effects. Farmers in Stara Pazova have to pay more attention to analyzing the possibility of creating machinery rings. Machinery rings to give their members a number of benefits and allow coming to the separation of farmers in two basic categories: (a) those who receive the service and (b) those that provide these services. Service providers are highly specialized only in specific operations, so that the quality of services at the highest level, and the services provided in this way with developed countries are not taxed and are considered the agreed production. At the same time, the 
maximum exploitation of mechanization, so the price of the services provided is lower. On the other hand, recipients can devote to other problems of its agricultural production (inputs, product placement) and not be burdened with their "unused" equipment. By creating machinery rings to achieve a more efficient agricultural production due to more rational use of existing resources, while simultaneously fulfilled to economies of scale and economies of scale.

Storage and finishing capacities for agriculture. Data from the Agricultural Census 2012 (Volume 2) show that in Stara Pazova in agricultural holdings recorded the following number and capacity of storage and additional processing capacity:

- Goals for corn - 2,817 (own capacities: 129,451 m3; used capacities: 53,237 m3);

- The granaries - 271 (own capacities: 9,602 m3 capacities used: 5,285 m3);

- $\quad$ Silos - 37 (own capacities: 26,277 t; used capacities: 27,113 t);

- Dryers - 217 (own capacities: 24.112m3; used capacities: 27,109 m3);

- Facilities for silage - 30 (own capacities: 5,544 m3 capacities used: 4,203 m3);

- Facilities for storing agricultural machinery and equipment - 1,627 (own capacities: 105,202 m2; used capacities: $94.903 \mathrm{~m} 2$ );

- Refrigerators - 14 (own capacities $5276 \mathrm{~m} 3$ capacities used: $5070 \mathrm{~m} 3$ );

- Facilities for storing cattle - 1,031 (own capacities: 11.730, seats, used capacities: 4,664, seats);

- Facilities for the accommodation of pigs - 4,827 (own capacities: 93,503, seats, used capacities of 50,229, the number of seats);

- Facilities for housing laying hens - 1,911 (own capacities: 170,181, seats, used capacities: 95,333, seats);

- Facilities to accommodate other livestock - 738 (own capacities: 19,067, seats, used capacities: 23,926, seats);

- Machine calibration, vacuum and packaging - 3 (own: 1, others: 2).

Cold storage for fresh and frozen fruits. The data presented in Table 3 show that even $71.65 \%$ of the total capacity of cold storage for agricultural holdings registered of the inner circle of Stara Pazova $(3,780 \mathrm{~m} 3)$. Then follow settlements: Golubinci (608 m3), Stari Banovci (528 m3), Surduk (300 m3) and Nova Pazova (60 m3). The resorts Belegiš, Vojka, Krnješevci Novi Banovci and are not recorded capacity refrigerator. 
Table 3. Refrigerators in Srem the area of and Stara Pazova, 2012 $2^{\text {th }}$

\begin{tabular}{|l|c|c|c|c|c|c|}
\hline $\begin{array}{c}\text { Area, town, } \\
\text { village }\end{array}$ & $\begin{array}{c}\text { The number of households } \\
\text { that own this property }\end{array}$ & $\begin{array}{c}\text { Number of } \\
\text { objects }\end{array}$ & $\begin{array}{c}\text { Overall } \\
\text { capacity }\end{array}$ & $\begin{array}{c}\text { Capacity } \\
\text { used }\end{array}$ & $\begin{array}{c}\text { The number of } \\
\text { households that } \\
\text { use only the alien } \\
\text { objects }\end{array}$ & $\begin{array}{c}\text { The number of } \\
\text { households that } \\
\text { use objects in } \\
\text { other purposes }\end{array}$ \\
\hline Srem area & $\mathbf{1 1 3}$ & $\mathbf{1 4 7}$ & $\mathbf{1 3 5 . 8 0 9}$ & $\mathbf{6 5 . 5 2 8}$ & $\mathbf{1 7}$ & $\mathbf{1 6}$ \\
\hline Stara Pazova & $\mathbf{1 1}$ & $\mathbf{1 4}$ & $\mathbf{5 . 2 7 6}$ & $\mathbf{P}$ & $\mathrm{P}$ & $\mathbf{2}$ \\
\hline Belegiš & $\mathrm{P}$ & $\mathrm{P}$ & 0 & $\mathrm{P}$ & $\mathrm{P}$ & 0 \\
\hline Vojka & $\mathrm{P}$ & $\mathrm{P}$ & 0 & $\mathrm{P}$ & $\mathrm{P}$ & 0 \\
\hline Golubinci & 4 & 4 & 608 & $\mathrm{P}$ & $\mathrm{P}$ & 0 \\
\hline Krnješevci & $\mathrm{P}$ & $\mathrm{P}$ & 0 & $\mathrm{P}$ & $\mathrm{P}$ & 0 \\
\hline Nova Pazova & $\mathrm{P}$ & $\mathrm{P}$ & 60 & $\mathrm{P}$ & $\mathrm{P}$ & 0 \\
\hline Novi Banovci & $\mathrm{P}$ & $\mathrm{P}$ & 0 & $\mathrm{P}$ & $\mathrm{P}$ & 0 \\
\hline Stara Pazova & $\mathrm{P}$ & $\mathrm{P}$ & 5.780 & $\mathrm{P}$ & $\mathrm{P}$ & \\
\hline Stari Banovci & 4 & $\mathrm{P}$ & 300 & $\mathrm{P}$ & $\mathrm{P}$ & 1 \\
\hline Surduk & $\mathrm{P}$ & $\mathrm{P}$ & $\mathrm{P}$ & 1 \\
\hline
\end{tabular}

Source: Census of Agriculture 2012, Agricultural objects, the level of the village, Republic Statistical Office, Republic of Serbia.

Note: In accordance with the Law on Official Statistics and the protection of personal data, some data in the tables for settlements with three or less than three holdings are hidden or displayed with the letter "P".

Silos; In Stara Pazova registered 18 farms that have silos. The data presented in Table 4 show that the largest capacity silos have the following settlements: Stara Pazova $(20,542$ t), Belegiš (2,060 t), Golubinci (1,515 t) and Vojka (1,200 t).

Table 4. Silos in Srem the area of and Stara Pazova, 2012 th

\begin{tabular}{|c|c|c|c|c|c|c|}
\hline $\begin{array}{c}\text { Area, town, } \\
\text { village }\end{array}$ & $\begin{array}{c}\text { The number of households } \\
\text { that own this property }\end{array}$ & $\begin{array}{c}\text { Number of } \\
\text { objects }\end{array}$ & $\begin{array}{c}\text { Overall } \\
\text { capacity }\end{array}$ & $\begin{array}{c}\text { Capacity } \\
\text { used }\end{array}$ & $\begin{array}{c}\text { The number of } \\
\text { households that } \\
\text { use only the alien } \\
\text { objects }\end{array}$ & $\begin{array}{c}\text { The number of } \\
\text { households that } \\
\text { use objects in } \\
\text { other purposes }\end{array}$ \\
\hline Srem area & $\mathbf{2 7 6}$ & $\mathbf{6 1 5}$ & $\mathbf{2 1 7 . 2 2 6}$ & $\mathbf{1 7 9 . 3 4 1}$ & $\mathbf{1 . 4 2 4}$ & $\mathbf{1 7 1}$ \\
\hline Stara Pazova & $\mathbf{1 8}$ & $\mathbf{3 7}$ & $\mathbf{2 6 . 2 7 7}$ & $\mathbf{2 7 . 1 1 3}$ & $\mathbf{7 2}$ & $\mathbf{5}$ \\
\hline Belegiš & $\mathrm{P}$ & $\mathrm{P}$ & 2.060 & 4.320 & 67 & 5 \\
\hline Vojka & $\mathrm{P}$ & $\mathrm{P}$ & 1.200 & $\mathrm{P}$ & $\mathrm{P}$ & 0 \\
\hline Golubinci & $\mathrm{P}$ & 11 & 1.515 & $\mathrm{P}$ & $\mathrm{P}$ & 0 \\
\hline Krnješevci & $\mathrm{P}$ & $\mathrm{P}$ & 0 & $\mathrm{P}$ & $\mathrm{P}$ & 0 \\
\hline Nova Pazova & $\mathrm{P}$ & $\mathrm{P}$ & 0 & $\mathrm{P}$ & $\mathrm{P}$ & 0 \\
\hline Novi Banovci & $\mathrm{P}$ & 7 & 20.542 & $\mathrm{P}$ & $\mathrm{P}$ & 0 \\
\hline Stara Pazova & 4 & $\mathrm{P}$ & 650 & $\mathrm{P}$ & $\mathrm{P}$ & \\
\hline Stari Banovci & $\mathrm{P}$ & $\mathrm{P}$ & 310 & $\mathrm{P}$ & $\mathrm{P}$ & 0 \\
\hline Surduk & $\mathrm{P}$ & & & $\mathrm{P}$ & 0 \\
\hline
\end{tabular}

Source: Census of Agriculture 2012, Agricultural objects, the level of the village, Republic Statistical Office, Republic of Serbia.

Note: In accordance with the Law on Official Statistics and the protection of personal data, some data into the tables for settlements of three or less than three holdings are hidden or displayed with the letter "P".

Average capacity silos on farms are 1459.83 t. On the other hand, the settlement Novi Sad, Nova Pazova and Krnješevci have the capacity silo. Companies that own silos are: Napredak AD Stara Pazova (Delta Agrar; 20,000 t); ZZ agricultural prom, Stara 
Pazova (17,000 t), Lazic agricultural -commerce, Golubinci (20,000 t); Poljoagrar, Vojka (17,000 t).

The granaries; According to the data given in Table 5 of 226 farms in Stara Pazova possesses barns. Maximum total capacity is located in the village Vojka $(2,755 \mathrm{~m} 3)$, followed by Stara Pazova (1,476 m3), Krnješevci (1,287 m3) and Golubinci $(1,181$ $\mathrm{m} 3$ ). Average capacity per farm, which has owned these facilities amounts to $42.5 \mathrm{~m} 3$.

Table 5. The granaries in Srem the area of and Stara Pazova, 2012 ${ }^{\text {th }}$

\begin{tabular}{|c|c|c|c|c|c|c|}
\hline $\begin{array}{l}\text { Area, town, } \\
\text { village }\end{array}$ & $\begin{array}{l}\text { The number of households that } \\
\text { own this property }\end{array}$ & $\begin{array}{l}\text { Number of } \\
\text { objects }\end{array}$ & $\begin{array}{l}\text { Overall } \\
\text { capacity }\end{array}$ & $\begin{array}{c}\text { Capacity } \\
\text { used }\end{array}$ & $\begin{array}{c}\text { The number of } \\
\text { households that } \\
\text { use only the alien } \\
\text { objects }\end{array}$ & $\begin{array}{l}\text { The number of } \\
\text { households that } \\
\text { use objects in } \\
\text { other purposes }\end{array}$ \\
\hline Srem area & 2.584 & 2.793 & 110.022 & 52.284 & 34 & 211 \\
\hline Stara Pazova & 226 & 271 & 9.602 & 5.285 & 6 & 19 \\
\hline Belegiš & 33 & 41 & 1.162 & 699 & 4 & 4 \\
\hline Vojka & 72 & 94 & 2.755 & $P$ & $\mathrm{P}$ & 1 \\
\hline Golubinci & 31 & 35 & 1.181 & $\mathrm{P}$ & $\mathrm{P}$ & 7 \\
\hline Krnješevci & 25 & 35 & 1.287 & $\mathrm{P}$ & $\mathrm{P}$ & 0 \\
\hline Nova Pazova & 4 & 4 & 102 & $\mathrm{P}$ & $\mathrm{P}$ & 1 \\
\hline Novi Banovci & $\mathrm{P}$ & $\mathrm{P}$ & 105 & $\mathrm{P}$ & $\mathrm{P}$ & 1 \\
\hline Stara Pazova & 32 & 33 & 1.476 & $\mathrm{P}$ & $\mathrm{P}$ & 3 \\
\hline Stari Banovci & 17 & 17 & 707 & $P$ & $\mathrm{P}$ & 1 \\
\hline Surduk & 9 & 9 & 827 & $\mathrm{P}$ & $\mathrm{P}$ & 1 \\
\hline
\end{tabular}

Source: Census of Agriculture 2012, Agricultural objects, the level of the village, Republic Statistical Office, Republic of Serbia.

Note: In accordance with the Law on Official Statistics and the protection of personal data, some data onto the tables for settlements of three or less than three holdings are hidden or displayed with the letter "P".

Dryers are recorded at 70 farms in Stara Pazova. According to the Census of Agriculture 2012 (Agricultural facilities, the level of settlements) facilities dominantly dryer are located in Stara Pazova (12.767 m3) and Golubincima (11,034 m3). In other settlements are recorded smaller capacity driers: Belegiš (144 m3), Stari Banovci (71 m3) Vojka (44 m3), Nova Pazova (38 m3) and Krnješevci (14 m3). Average continuous dryers on farms are $344.5 \mathrm{~m} 3$. In Golubincima has much drier tobacco because tobacco production is largely present in this village. It used to be of vegetables. Dryers, privately owned, bother, because the population is spread odors from tobacco. Also, consume a lot of gas to work. They were found geothermal water that could be used to heat the kilns one that would be used for all tobacco (Report of the working group meeting Stara Pazova, 22.12.2015). Facilities for silage are listed at 25 farms in Stara Pazova (Census of Agriculture 2012, Agricultural objects, the level of the village). Average capacity of the farms that have this facility is $221.8 \mathrm{~m} 3$. Maximum total capacity of facilities for silage located in Belegišu (1,464 m3), followed by: Golubinci (1,447 m3), Stara Pazova (1,241 m3), Krnješevci (749 m3).

Machine calibration, a vacuum packaging and in Stara Pazova has a total of 3 (Census of Agriculture 2012, Agricultural machinery, the level of the village), while all younger 
than 10 years, and it is evident that the existing fleet technology in a better position than the average in the Republic of Serbia. The capacity of machine calibration, vacuum and packaging is located in settlements Belegiš and Stara Pazova.

Processing of agricultural products; the complex about primary processing of agricultural products allowed the construction trades facilities for primary processing of agricultural products plant and animal origin in accordance with traditional technology climate: fruits, vegetables, herbs, milk, meat, grain sorghum, cane, wool (Spatial plan of Stara Pazova to 2025). Installations for processing agricultural products can be built with agricultural facilities, in order to complete the production cycle (Spatial plan of Stara Pazova to 2025). Some of the important agricultural companies in Stara Pazova were Žitopromet-Mlinpek D.O.O and Panonija-Marketing LLC, which is engaged in the manufacture of grain mill products. They also have a mill for the production of flour (http://mtt.gov.rs/informacije/baza-trgovackih-preduzeca-i-preduzetnika). Company Miljković V. Silosi DOO is also important, but not more engaged in processing trade of grain, unmanufactured tobacco, seeds and animal feeds. The main limiting factors of greater and more effective involvement of the food industry in the international market are the following: 1) Poor range of food products in relation to the offer in the developed world; 2) In the structure of export of Serbian agriculture is dominated by products of primary agricultural production, while higher processing products account for only about a fifth of exports (Jeremić, Milojevic, Terzic, 2016); 3 ) Fluctuations in market quality products, either due to lack of standards, either because of noncompliance and poor control of applicable standards; 4) The lack of long-term and solid contractual relations or proprietary connection between the food industry and manufacturers of raw materials (primary agricultural production). The products are increasingly the result of cultural, social and political dimensions. "These trends in the markets, driven by economic, social and cultural changes, encourage new forms of production and business models in developed processing industries, where the added value is created through the services, experience and stories related to the products, and not through the physical process of production. (Manniche, Test, 2010).

Development priorities; Using comparative advantages and tradition, which are the municipality of Stara Pazova in the field of agricultural production, can go in the direction of the transformation of local agriculture, as well as all entities involved in economic activity in this sector of the economy. These processes of transformation must go in the direction of the review of existing and development of new business and marketing strategies of farmers, based on developmental skills and strengths of the producers, but also on knowledge of consumer preferences, new technologies, marketing approaches and other postulates of modern market economy. In such circumstances, consideration of market access, i.e. constant and intensive changes in the market, is the first and basic assumption on which it would be rational to formulate new marketing strategies, other than just by competing ingenuity, technology and quality. Agricultural companies have had to develop a new concept of management and marketing, in order on the basis of new market and economic conditions, could develop a profitable business strategy 
and ensuring growth of production and sales (Cvijanovic, Trandafilović, Imamovic, 2013). Storage and finishing facilities in Stara Pazova exist, but must be done in improving these capacities: continued construction, purchase, expansion and respect for environmental standards. Also, it is necessary to work on the construction of a collective urban large distribution center, which would be a public-private partnership, the trademark uniform and packaging of agricultural products. Bearing in mind the agricultural potentials for the municipality of Stara Pazova, development priorities are as follows: 1) Growth of agricultural production and competitiveness while adapting to the demands of the domestic and foreign market, based on the application of modern, high tech, appreciation of veterinary and phytosanitar,s standards, environmental standards and animal welfare; 2) The development of the sector of agricultural products through the application of knowledge and innovation, respect for the standards of food quality and safety, and respect for the principles of sustainable development; 3) Encouraging mergers and strengthening local entrepreneurial initiatives population of the production and processing of agricultural products, with the aim of creating a stable and high income farmers (income that is in line with other parts of the economy), which provides a satisfactory standard of living; 4) Sustainable management of natural resources and environmental protection in rural and peri-urban settlements; 5) The preservation and protection for biodiversity in rural and peri-urban areas; 6) The preservation of genetic resources in agriculture and protection of biodiversity; 7) Improving the quality of life in rural and peri-urban settlements of investment in physical and social infrastructure and the development of services, while preserving the cultural and natural heritage; 8) The creation of new jobs of rural and peri-urban settlements and the growth of living standards of the population of these settlements (Rural Development Strategy of the Municipality of Stara Pazova for the period 2015 to 2025 years).

In the coming period the emphasis must be placed on the development of the food industry that is focused on meeting the needs and desires for consumers, with an emphasis on innovation, quality, high level of food hygiene and food safety standards. There are great opportunities and potentials of the domestic food industry in the production of safe food of high quality, which is very interested in foreign markets, which will include the introduction to ISO standards and HACCP quality systems in all processing capacities. Development policy of the food industry surely will follow global economic trends (such as concentration capacity and capital, the introduction of highly sophisticated technology), and in this process the role of the state is important, both from the standpoint of security and protection of competition and control abuse monopoly position, and the aspect fiscal and investment support to small and mediumsized processing capacities, especially in rural areas. 


\section{Conclusion}

Development of rural areas is closely linked to the development of agriculture and processing of agricultural products, and agricultural production is traditionally the most important sector of the rural economy and the main source of income for the rural population. In accordance with that necessary investments in the development of micro-enterprises in the field of processing of agricultural products, as well as raising the value of products obtaining geographical indications. By investing in the said operations would improve the competitiveness of agricultural holdings in the market, increasing revenue holdings to improve their economic status, which would enable a better quality of life in rural areas of the municipality of Stara Pazova and reducing the rate of depopulation of rural areas. Conditions that contribute to the employment of the rural population are boosting entrepreneurship and the development of microenterprises. The vision of agriculture involves the development of propulsion and competitive agriculture made up of commercial and family farms engaged exclusively in agriculture or engaged in agriculture in terms of additional revenue sources. However, the desired future of this area will not happen by itself or because someone eager. The desired future and the achievement of the strategic objectives of Stara Pazova in agriculture require immediate action. Future economic vitality of local communities to a lesser extent is a function of available resources and geographical position, a strong leadership and a more effective strategy.

\section{Literature}

1. Analiza poljoprivrede i prehrambene industrije Srbije u 2015. godini, Udruženje za poljoprivredu, prehrambenu industriju, šumarstvo i vodoprivredu, Privredna komora Srbije (PKS), Beograd, mart 2016. godine.

2. Cvijanović, D., Trandafilović, S., Imamović, N. (2013): "Marketing koncept u funkciji razvoja poljoprivrednih preduzeća u tranzicionim zemljama“, Ekonomika poljoprivrede, vol. 60, no. 1, pp. 113-122.

3. IPARD II program za Srbiju (2014-2020), Ministarstvo poljoprivrede i zaštite životne sredine Republika Srbija, Beograd, 2014.

4. Izveštaj sa sastanka fokus grupe Stara Pazova - Bojana Bekić, Institut za ekonomiku poljoprivrede, Beograd, 22.12.2015.

5. Jeremić Zoran, Milojević Marko, Terzić Ivica (2016): “Poslovne performanse 15 najvećih izvoznika iz prehrambeno-prerađivačke industrije u periodu 2008-2014. godina", Ekonomika poljoprivrede, vol. 63, no. 3, pp. 943-957.

6. Maletić, R., Popović, B. (2016): "Proizvodni kapaciteti porodičnih poljoprivrednih gazdinstava Srbije i zemalja EU”, Teme 2016, vol. 40, no. 2, pp. 807-821.

7. Manniche, J., Testa, S. (2010): "Knowledge Bases in Worlds of Production: The Case of the Food Industry", Industry and Innovation, vol. 17, no. 3, pp. 263-284.

8. Milanović, M.R., Stevanović, S., Dimitrijević, B. (2016): “Agrarni potencijali u reindustrijalizaciji Srbije - potrebe i mogućnosti revitalizacije industrije agrarnih 
inputa", Ekonomika poljoprivrede, vol. 63, no. 1, pp. 143-158.

9. Nikolić, M. (2006): “Uporedna analiza starosne strukture seoskog stanovništva u opštinama Stara Pazova i Blace”, Ekonomika poljoprivrede, vol. 52, no. 1-2, pp. 142151.

10. Odluka o budžetu opštine Stara Pazova za 2016. godinu, ,Službeni list opština Srema“ broj 35/15; http:/www.starapazova.rs/images/stories/PDF/budzet/2016/Odluka\%20 o\%20budzetu\%20opstine\%20Stara\%20Pazova\%20za\%202016.godinu.pdf date of access: 10.02.2016.

11. Petrović, Ž., Čikić, J. (2005): "Savetodavstvo kao činilac ruralnog razvoja Srbije“, Međunarodni naučni skup: Multifunkcionalna poljoprivreda i ruralni razvoj, 08-09. decembar, Institut za ekonomiku poljoprivrede, Beograd, pp. 354-362.

12. Popis poljoprivrede 2012, Poljoprivredna mehanizacija, oprema i objekti u Republici Srbiji, Republički zavod za statistiku, Beograd.

13. Popis poljoprivrede 2012, Ostali podaci o gazdinstvu, nivo naselja, Republički zavod za statistiku, Beograd.

14. Popis poljoprivrede 2012, Poljoprivredni objekti, nivo naselja, Republički zavod za statistiku, Republika Srbija.

15. Popis poljoprivrede 2012, Knjiga 2. Republički zavod za statistiku, Beograd 2014.

16. Porter. M.,E. (1990): Competitive Advantage of Nations, The Free Press, New York.

17. Revizija strategije održivog razvoja Opštine Stara Pazova 2010-2020. godine, Pokrajinski sekretarijat za međuregionalnu saradnju i lokalnu samoupravu, Opština Stara Pazova, decembar 2015. http://www.starapazova.rs/images/stories/opstinske odluke_pdf/Revizija\%20Strategije $\% 20$ odrzivog $\% 20$ razvoja $\% 20$ opstine $\% 20$ Stara $\% 20$ Pazova\%202010-2020.pdf; date of access: 10.02.2016.

18. Prostorni plan opštine Stara Pazova do 2025. godine, Javno urbanističko preduzeće, Stara Pazova, decembar 2011.

19. Regulativa 1305/2013 (Regulation (EU) No 1305/2013 of the European Parliament and of the Council of 17 December 2013 on support for rural development by the European Agricultural Fund for Rural Development (EAFRD) and repealing Council Regulation (EC) No 1698/2005 (OJ L 347, 20.12.2013, p. 487)).

20. Savić, LJ., Bošković, G., Mićić, V. (2016): “Agricultural industrija Srbije - potencijali i perspective", Ekonomika poljoprivrede, vol. 63, no. 1, pp. 107-122.

21. Strategija poljoprivrede i ruralnog razvoja Republike Srbije za period 2014-2020. godine, Službeni glasnik Republike Srbije broj 85/14.

22. Strategija ruralnog razvoja opštine Stara Pazova za period 2015 - 2025 godine, Institut za ekonomiku poljoprivrede, Beograd, 2016

23. Van den Ban, A.W., Hawkins, H., S. (1996): Agricultural Extension, Blackwell Science, UK.

24. http://www.polj.savetodavstvo.vojvodina.gov.rs/book/export/html/2178; date of access: 10.02.2016.

25. http://www.starapazova.rs/opstina-stara-pazova/obrazovanje/srednje-skole.html; date of access: 10.02.2016. 
26. http://mtt.gov.rs/informacije/baza-trgovackih-preduzeca-i-preduzetnika/t20836245; date of access: 17.02.2016.

\title{
POLJOPRIVREDNI POTENCIJALI I RAZVOJNI PRIORITETI OPŠTINE STARA PAZOVA ${ }^{5}$
}

\author{
Branko Mihailovićc ${ }^{6}$ Zoran Simonovićc Nikola Ćurčičc ${ }^{7}$
}

\begin{abstract}
Apstrakt
U radu se istražuju poljoprivredni potencijali opštine Stara Pazova, te se shodno tome definišu ravojni prioriteti $u$ ovoj oblasti. Cilj istraživanja je sagledavanje realnih mogućnosti za unapređenje agrara Opštine. Analiza je fokusirana na: transfer znanja $i$ inovacija, agrotehničku opremljenost, skladišne i doradne kapacitete u poljoprivredi, preradu poljoprivrednih proizvoda i viziju i razvojne prioritete u poljoprivredi Opštine. Rezultati istraživanja pokazuju da unapređenje konkurentnosti poljoprivrednog sektora opštine Stara Pazova zahteva realizaciju adekvatnih strateških mera i projekata na planu unapređenja ljudskog potencijala, većeg stepena prerade poljoprivrednoprehrambenih proizvoda, kao i bolju agrotehničku opremljenost poljoprivrednih proizvođača. Aktivnosti na ovom planu uključuju pre svega, veću povezanost nauke $i$ prakse preko reorganizovanih poljoprivrednih stanica, savetodavne službe, matične službe, zemljoradničkih zadruga $i$ drugih udruženja poljoprivrednika; razvoj $i$ implementaciju novih znanja i veština poljoprivrednika kroz savete, obuke, seminare, kurseve; podršku mladim poljoprivrednicima u modernizaciji gazdinstva. Svi projekti $u$ ovoj oblasti moraju bazirati na adekvatnoj državnoj podršci $i$ koordiniranim aktivnostima javnog i privatnog sektora.
\end{abstract}

Ključne reči: poljoprivreda, transfer znanja, skladišni i doradni kapaciteti, razvojni prioriteti.

5 Rad je deo istraživanja na projektu broj III 46006: „Održiva poljoprivreda i ruralni razvoj u funkciji ostvarivanja strateških ciljeva Republike Srbije u okviru dunavskog regiona“ koji finansira Ministarstvo prosvete, nauke i tehnološkog razvoja Republike Srbije u periodu 2011-2017.

6 Dr Branko Mihailović, Viši naučni saradnik, Institut za ekonomiku poljoprivrede, Volgina ulica br. 15, 11060 Beograd, Srbija, Telefon: 01169728 42, E-mail: brankomih@neobee.net.

7 Dr Zoran Simonović, Naučni saradnik, Institut za ekonomiku poljoprivrede, Volgina ulica br. 15, 11060 Belgrade, Srbija, Telefon: 01169728 58, E-mail: zoki@medianis.net.

8 Nikola Ćurčić M.A., Asistent u nastavi, Univerzitet Union, „Nikola Tesla“, Beograd, Fakultet za menadzment, Njegoševa 1a, 21205, Sremski Karlovci, Srbija, Telefon: 02121 550 45, nikolavcurcic@yahoo.com. 
ECONOMICS OF

AGRICULTURE

\section{CONTENT}

1. Željko Anđelković, Aleksandra Dragin, Sanja Božić, Kristina Košić

EMOTIONAL EXHAUSTION AND JOB SATISFACTION OF TOUR GUIDES IN RURAL AREAS . . . . . . . . . . . . . . 11

2. Sanja Đukić, Danica Glavaš-Trbić, Nikola Banjac

MANAGEMENT PROBLEMS OF RURAL DEVELOPMENT IN FRUŠKA GORA . . . . . . . . . . . . . . . . . . . . 27

3. Ivana Ilić, Bojan Krstić, Sonja Jovanović

ENVIRONMENTAL PERFORMANCES OF AGRICULTURE IN THE EUROPEAN UNION COUNTRIES . . . . . . . . . . . . . 41

4. Nataša Kljajić, Jonel Subić, Zorica Sredojević

PROFITABILITY OF RASPBERRY PRODUCTION

ON HOLDINGS IN THE TERRITORY OF ARILJE. . . . . . . . . . . 57

5. Aleksandar Maksimović, Zoran Grgić, Ferhat Ćejvanović

MULTI-ATTRIBUTE ANALYSIS OF ORCHARD ACCORDING

TO THE INTEGRATED PRODUCTION CONCEPT . . . . . . . . . . 69

6. Ozrislava Milinković, Branislav Jakić, Slobodan Vuksanović,

Dragana Macura, Milica Šelmić

MULTI- CRITERIA DECISION BASED APPROACH

TO SELECTING THE TYPE OF INDUSTRIAL HALLS

USED IN FOOD INDUSTRY $\ldots \ldots \ldots \ldots$. . . . . . . . . . 81

7. Gordana Nikić, Ljubiša Stamatović, Azra Sućeska

EMOTIONAL COMPETENCIES AND PERSONALITY

TRAITS OF MANAGERS IN MODERN AGROBUSINESS. . . . . . . .97

8. Vladimir Obradović, Nemanja Karapavlović

FINANCIAL REPORTING OF COMPREHENSIVE INCOME

IN THE FOOD AND BEVERAGE SECTOR

IN THE REPUBLIC OF SERBIA . . . . . . . . . . . . . . 113 
9. Aleksandar Ostojić, Nebojša Savić, Željko Vaško

CONSUMER ATTITUDES

ON BUYING FISH IN BANJA LUKA . . . . . . . . . . . . . . . 129

10. Radivoj Prodanović, Boris Kuzman, David Jovović, Lazar Ozegović

MARKET AND TRADE OF ORGANIC FRUITS IN SERBIA $\ldots . . .141$

11. Predrag Vukadinović, Aleksandar Damnjanović, Ljiljana Dimitrijević

ANALYSIS OF THE SALES AND INCOMES BETWEEN

DIFFERENT CATEGORIES OF AGRICULTURAL PRODUCTS . . . 157

12. Jugoslav Aničić, Svetlana Vukotić, Goran Maksimović

THE POSSIBILITIES AND LIMITATIONS

OF ENTREPRENEURSHIP DEVELOPMENT

IN AGRICULTURE IN SERBIA . . . . . . . . . . . . . . 171

13. Željko Bjelajac, Marijana Dukić - Mijatović, Joko Dragojlović

FOOD SAFETY AS ONE OF THE MAIN SAFETY $P$

REOCCUPATIONS OF A MODERN MAN . . . . . . . . . . . . . 191

14. Milan Bradić, Ljiljana Kosar, Lukrecija Djeri, Svetlana Vukosav, Vuk Garača

ECO-LABELLING OF ACCOMMODATION FACILITIES

AND ITS PERCEPTION BY RURAL TOURISTS:

CASE STUDY OF VOJVODINA . . . . . . . . . . . . . . 205

15. Vaso Jegdić, Iva Škrbić, Srđan Milošević

MODELS OF ENTREPRENURSHIP DEVELOPMENT

IN RURAL TOURISM DESTINATIONS IN VOJVODINA . . . . . . . 221

16. Duško Kuzović

MUSEUM OF VERNACULAR ARCHITECTURE OF WESTERN SERBIA

- Representative curtilages of the area surrounding middle

course of the river Drina and Podgorina . . . . . . . . . . . 239

17. Branko Mihailović, Zoran Simonović, Nikola Ćurčić

AGRICULTURAL RESOURCES AND DEVELOPMENT

PRIORITIES OF THE MUNICIPALITY OF STARA PAZOVA. . . . . 259

18. Radmilo Nikolić, Aleksandra Fedajev, Vidoje Stefanović, Silvana Ilić

THE AGRICULTURE SECTOR IN WESTERN BALKANS

- SOME CHARACTERISTICS OF DEVELOPMENT. . . . . . . . . . 275

19. Vladimir Njegomir, Rajko Tepavac, Nenad Ivanišević

ALTERNATIVE SOURCES OF FINANCING

ENTREPRENEURIAL UNDERTAKINGS IN AGRICULTURE . . . 295

Economics of Agriculture, Year 64, No. 1 (1-404) 2017, Belgrade 
20. Daniela Nuševa, Kristina Mijić, Dejan Jakšić

THE PERFORMANCES OF COFFEE PROCESSORS

AND COFFEE MARKET IN THE REPUBLIC OF SERBIA . . . . . . 307

21. Svetlana Roljević Nikolić, Predrag Vuković, Biljana Grujić

MEASURES TO SUPPORT THE DEVELOPMENT OF ORGANIC

FARMING IN THE EU AND SERBIA . . . . . . . . . . . . 323

22. ŽeljkoVojinović, Vera Zelenović, DragoCvijanović

PROGRAM OF STATE SUPPORT

TO AGRICULTURAL CREDITING. . . . . . . . . . . . . . . . 339

23. Nikola Vuksanović, Dragan Tešanović, Bojana Kalenjuk,

Milijanko Portić, Marija Knežević

SOCIO-DEMOGRAPHIC CHARACTERISTICS

AS DETERMINANTS OF DIFFERENCES

IN PERCEPTION OF LOCAL GASTRONOMY . . . . . . . . . . . . 359 